\title{
Evaluation of Implementation Policy on Management of School Operational Fund (BOS) 2019 with Edward III Model
}

\author{
Ary Rokhadiyati \\ Magister of Administration Education, UKSW, Jalan Diponegoro No, 52-60 Salatiga \\ *Corresponding author: 942018007@student.uksw.edu
}

\begin{abstract}
This study aims to evaluate the management of the School Operational Assistance (BOS) year 2019 at the Department of Education Culture Youth and Sport Semarang Regency. This is an evaluation research. Data were collected using documents study techniques, observation, and in-depth interviews. Data are validated by source and triangulation techniques. This study uses mixed method to get the whole pictures of the informant sources. What new about this research is that the data analysis technique uses the Edward III Model that looks at the factors of communication, resources, disposition and bureaucratic structure. The result of this study shows that implementation of School Operational Assistance (BOS) year 2019 is carried out in accordance with guidelines made by the government. The four aspects are all in very good categories. For communication aspect is in very good category because it gets 10 out of 12 points or $83 \%$. For Resources aspect is in very good category as well for its score is 16 out of 20 points or 80\%. While for Disposition aspect is in very good category because it gets 17 out of 20 points or $85 \%$. For the last aspect which is bureaucratic structure gets the highest points as it gets 8 out of 8 points or $100 \%$. Although the results are all very good, it still needs a little improvement on communication aspect especially on consistency factor since the guidelines has been revised for three times. Resources aspect on human resources quantity in BOS management team for there is only two persons managing 601 schools in Semarang Regency and also on disposition aspect because there is no incentive and award for the BOS management team. These results bring implication that the Department of Education in Semarang Regency can make improvement on the aspects which do not get maximal score and the for others Education Department in other Regencies or cities can learn from this research to manage BOS in better ways.
\end{abstract}

Keywords: School Operational Assistance, Management, Edward III Model.

\section{Introduction}

The 1945 Constitution in article 31 paragraph 1 states that every citizen has the right to education, because through education will create Human Resources (HR) that contribute to the progress of a nation. The government has made an update which includes the vision, mission and national education development strategy which is realized by the issuance of Law No. 20 of 2003 concerning the National Education System where in article 6 paragraph 1 states that every citizen aged seven to fifteen years is required to attend basic education. Then in article 34 paragraph 2 states that the government and regional government guarantee the implementation of compulsory education at the minimum level of basic education without charging fees. In paragraph 3 states that compulsory education is the responsibility of the government educational institutions, regional governments, and the community.

The consequences of Law No. 20 of 2003 that the government is obliged to provide educational services for all school age students in order to accelerate the 9-year compulsory education. The government has provided one of the educational services in the form of School Operational Assistance (BOS) since July 2005. This program is basically to fund non- 
personnel operating costs for basic education units as implementing compulsory education programs. The purpose of the School Operational Assistance (BOS) program is to ease the burden of the community on the educational costs of school operations and to improve community access, especially students from underprivileged families to qualified education (Setiawan, 2004). However, after almost 15 years the program has been launched out, the quality of education in Indonesia to be ranked 10th lowest according to the PISA report in 2018 (Silele et al., 2017). This study seeks to evaluate why this is happening, are there errors in the management of BOS funds that are not well targeted, especially management at the Department of Education. Other problems are in some cities and regencies in Indonesia many corruption cases arise in relation with BOS program in the Department of Education (Afifudin \& Beni Ahmad Saebani, 2009). In a study conducted by Nurtje, Irine, Djoys, and Guyen (2014: 6) about the distribution of BOS funds in the Education Department of Aru Island Regency also departed from the suspicion on a corruption practice of BOS funds at the time of direct distribution to schools as some persons in Education Department asking for fee from schools.

In accordance with the Technical Guidelines established by the Ministry of National Education regarding the use of BOS Funds, that in every city or regency must form a BOS management team so the implementation of School Operational Assistance can run smoothly, effectively, efficiently and can be accounted for. This study examines the management of the School Operational Assistance Fund (BOS) which is carried out at the Education Office in the 2019 fiscal year, using the Edward III Model which analyze factors that influence the implementation of policies guided by communication, resources, and disposition, and bureaucratic structure. The problem statement of this research is how communication, resources, disposition and structure of the bureaucracy in managing the BOS program policies in the Education Office of the Culture Education for Youth and Sports in Semarang Regency. While the purpose of this study is to evaluate the communication, resources, disposition and bureaucratic structure of BOS policies in the Department of Culture for Youth and Sports Education - Semarang regency in 2019.

\section{Materials and Methods}

This research is a policy evaluation study using mixed methods. According to Creswell (2010: 5) mixed method is a research approach that combines two forms of qualitative and quantitative research. In this study, quantitative data is used to explain 
qualitative data. This qualitative data was obtained through in-depth interviews with sources because researcher wants to understand the complexity of the phenomenon under study in order to collect the data needed, evaluate it and discuss everything related to the object (Moloeng, 2009). While quantitative data is used to calculate the results of research in the form of scoring of qualitative data that has been obtained. An instruments in a table form, containing numbers with the highest score of 4 and 1 for the lowest score is made to count each aspect on communication factors, sources, dispositions, and bureaucratic structures (Majid et.al., 2015) . The indicators for each aspect is scored based on the data obtained from qualitative data.

Researchers uses the Edward III Model and focuses the research on communication factors, sources, dispositions, and bureaucratic structures in carrying out School Operational Fund (BOS) in the Department of Education Culture Youth and Sport Semarang Regency. This research is a field research with the focus on whether the evaluation of the implementation of the School Operational Assistance (BOS) management policy is in accordance with the stated objectives of the policies (Neolaka, 2014). The data collected is primary data and secondary data. The primary data are obtained through direct interviews with data sources and research informants or interviewees that have been determined. Secondary data is supporting data obtained from written documents at the Semarang Regency Culture, Youth and Sports Education Department.

The data sources in this study are staff members in the Semarang Regency BOS management team as the main source of research. The main instrument is the researcher herself and several supporting documents. While the methods or data collection techniques used are interview with resource persons directly, observation of all events or phenomena which are the focus of research and documentation of what is available at the research location.

The analysis technique used in this study is an interactive analysis model (Miles and Hubermann, in Rohidi and Mulyarto, 1992). The first technique is Data Reduction to determine the data in accordance with the problems to be investigated. The second is Data Display to understand what is happening and can plan further work based on that understanding. In qualitative research data presentation is usually narrative (Sugiyono, 2010). The last step is Conclusion Drawing or Verification on the results of data analysis. Conclusions must answer the research problem statement. 


\section{Results and Discussion}

Researchers uses the Edward III Model and focuses the research on communication factors, sources, dispositions, and bureaucratic structures in carrying out School Operational Costs (BOS) in the Department of Culture and Youth Education and Sport Semarang Regency. According to Edward III (1975, quoted from Widodo, 2012, p.96) there are 4 factors that influence the success or failure of policy implementation, namely communication, resource, disposition, bureaucratic structure, and communication factor.

Information about public policies must be conveyed to staff so that they know what needs to be prepared and done to implement the policy, hence the goals and objectives of the policy can be achieved as expected (Arikunto, 2013). Important factors in the information delivery are transmission (how to deliver), clarity and consistency. Resources play an important role in policy implementation (Sulistyaningrum, 2016). Resources include human resources, budget resources, and facilities and information resources. Disposition is said to be the will, desire and tendency of staff to implement a policy with full commitment so the policy's objectives can be achieved. If the implementer has good attitudes then he will be able to implement the policy as well as what is desired by policy makers (Edward III 1980: $11)$.

According to Edwards, there are two main characteristics of bureaucracy: work procedures or often called SOPs and fragmentation. Bureaucratic structure is all organizational instruments as a whole and structured. There are two aspects of organizational structure, namely the mechanism and fragmentation. The mechanism is generally made in the form of Standard Operational Procedure (SOP). Problems in implementation will arise when the bureaucracy is too long and is not accompanied by the division of coordination and responsibility. The length of the bureaucratic structure results in bureaucratic fragmentation.

There is a good transmission or communication channel between the central, provincial and regency government and schools (Wahab et al., 2008). This is because in addition to the detailed implementation of technical guidelines from the central government namely Permendikbud No.3 of 2019 there is also a Circular Letter from the Minister of Home Affairs Number 971-7791 2018 as a guideline for implementation. The two guidelines are also socialized intensively to district and provincial level BOS management teams and also to education units receiving BOS funds. Because all implementers adhere to the same technical guidelines, communication channels become smoother and clearer (Kaswandi, 2015). 
Meanwhile, the clarity of information received by the BOS management team is also quite clear. It is known that the BOS implementers at the regency level understand well what the BOS program is and how to carry out their duties. For the consistency, general information about BOS is clear to be done but there are obstacles encountered related to changes in existing technical guidelines. The BOS technical guidelines for the 2019 fiscal year underwent three times changes namely number 3 then replaced with number 18 and replaced again with number 35 for the attachment section.

In the Minister of Education and Culture Regulation No. 3 of 2019 concerning Technical Guidelines for Regular School Operational Assistance, the regulation on the procurement of goods and services online was not yet through the information system (Widyatmoko et al., 2017). So it was felt necessary to replace the regulation with a new rule namely Permendikbud No. 18 of 2019 which was subsequently changed back to the addition on chapter IV in appendix II of Permendikbud number 35 of 2019 concerning the Procurement System for Goods and Services in Schools (SIPLah). SIPLah is used for the procurement of goods and services whose funds are sourced from BOS funds and or other funds. The provision is made online through SIPLah stipulation by the official in accordance with his authority. With sudden technical changes, there is inconsistency in the management of BOS funds (Iskandar, 2009). This is due to the fact that not all suppliers are willing to make SIPLah applications in order to provide goods and services for school needs. So in this case the school buys items at an improper supplier. For example, schools buy brooms at computer suppliers, because computer suppliers already have the SIPLah application.

Table 1. Evaluation on Communication Aspects

\begin{tabular}{lc}
\hline \multicolumn{1}{c}{ Indicator } & Value \\
\hline There are good communication channels, between policy makers and policy & $4 / 4$ \\
implementers, the implementation team and budget users & $3 / 4$ \\
Policies are easy to understand, there is no controversy about policies, clear & \\
technical guidelines are available, information about programs is clearly conveyed & $3 / 4$ \\
and received & $10 / 12$ \\
Information and orders for BOS program policies are consistent and clear & Total \\
\end{tabular}

Source: Processed level data

Table 1 . Shows $83 \%$ or very good, however in 2 aspects of communication only get 3 points from four points. These aspects are on clarity and consistency. While the aspect that gets the maximum score is transmission where there is good communication channels between policy makers and policy implementers about the implemented policies.

\section{Resource Factor}


There are two aspects for Human Resources namely quantity and quality (Gunawan, 2014). In terms of quantity, the existing human resources in the BOS management team of Semarang Regency do not meet the requirements, because there are only 2 officers who have to handle a total of 601 elementary and junior high schools receiving BOS funds. Whereas in terms of quality, the team members have sufficient skills to handle BOS, for they have good educational background by having bachelor degree minimally. In addition, they often receive training and outreach on how to manage BOS funds.

The next resource is budget resources. In terms of the budget allocated for the management team in carrying out the BOS program is sufficient (Winarno, 2005). This budget is included in the Semarang Regency budget and is largely used for socialization and monitoring costs at schools and inviting treasurers and school principals to come to the Education Department Office.

The third resource is facility resources that do not meet the requirements. The BOS implementers in the Semarang Regency Office are lacks of adequate space. This room is too narrow to accommodate a large number of report files from a total of 601 schools consisting of 498 elementary schools and 103 junior high schools that receive BOS. There are numbers of shelves in the BOS management team's room, but clearly they are unable to accommodate the large amount of collected files, then the files are finally placed on the floor, so it makes this room less comfortable for work.

The fourth is information resources namely the relevance and suitability of the information obtained about the BOS program in accordance with its objectives, which are considered to be very good. Existing Technical Guidelines No. 3 of 2019 which was subsequently replaced by Technical Guidelines No. 18 in 2019 and then Technical Guidelines No. 35 of 2019 has helped providing guidance on the implementation of BOS management in the Education Office. In addition to technical guidelines, there is also Circular Letter Number 971-7791 of 2018 dated September 28, 2018 issued by the Minister of Home Affairs of the Republic of Indonesia concerning Technical Guidelines for Budgeting, Implementation and Administration as well as Accountability of Operational Assistance Funds for Schools of Primary and Primary Education organized by Regencies or Cities in the Budget Regional Revenue and Expenditure (APBD). In terms of information, there are regular internal and external coordination within the implementation team that is carried out regularly, but sometimes it is also spontaneously or when there are urgent problems arising. An assessment of the policy implementation for these aspects of resources if quantified is as follows: 
Table 2. Evaluation for Resource Aspects

\begin{tabular}{lc}
\hline \multicolumn{1}{c}{ Indicator } & Value \\
\hline $\begin{array}{l}\text { The number Human Resource of BOS Management Team to implement the BOS } \\
\text { program is sufficient }\end{array}$ & $2 / 4$ \\
The quality Human Resources of the BOS Management team to implement this & $4 / 4$ \\
program is good & \\
There are adequate facilities to support the implementation of the BOS program & $3 / 4$ \\
There is relevance and appropriateness of information regarding the BOS program & $4 / 4$ \\
with its goal & $3 / 4$ \\
There is sufficient budget to implement the BOS program & $16 / 20$ \\
Total & $85 \%$ \\
\hline
\end{tabular}

Table 2 above shows that for the aspects of Resources get a value of 16 from a maximum value of 20. In the aspect of the number of human resources getting a value of 2 from a maximum value of 4 because the number of personnels available to manage BOS funds is only two people to manage 601 schools in Semarang Regency. For facilities and budget aspects get a value of 3 from a maximum value of 4 , because the facilities used in managing BOS funds are inadequate. Likewise, the budget is considered sufficient to manage this BOS fund. Whereas the quality of implementing HR shows maximum value. Likewise, the suitability of information about BOS with its objectives also receives a very good value.

\section{Disposition Factor}

The willingness, dedication or view of the executor in this case the BOS management team to carry out the BOS program is good, marked by the results of the Audit Board of the Republic of Indonesia or BPK which are always declared to be Fair without Exception (WTP). This shows that the managements of the BOS program do not experience problems. The commitment of the BOS management team implementers can also be seen from the working hours that sometimes exceed what they should. For example, working on Saturdays which should be a day off but sometimes they still go to work, either in the office to complete all administration related to BOS or for socialization and checks to certain schools.

In terms of expertise, the executors in the BOS management team in Semarang Regency is able to carry out tasks as written in the technical guidelines. There are 12 activities of task as follows : 1. To train, guide and encourage Elementary and Junior High Schools to include basic education data in the Dapodik; 2. Provide guidance to Elementary and Junior High Schools in the management and reporting of Regular BOS; 3. Verify the data completeness on the number of students and the account numbers of Elementary and Junior 
High Schools whose accuracy is doubtful; 4. Verify Elementary and Junior High Schools that meet the requirements and criteria for receiving Regular BOS funds with a minimum allocation; 5.Signed the NPH with the Provincial government representing Elementary and Junior High Schools ; 6. Reprimand and order to make reports for Elementary and Junior High Schools who have not made reports to be submitted to the provincial government; 7.Collect and recapitulate reports on the realization of the distribution of BOS Regular Elementary and Junior High School 8. Collect and recapitulate reports on the use of BOS Regular Elementary and Junior High School funds; 9. Providing services and handling public complaints by providing information channels specifically BOS Regular; 10. Monitor the development of basic education data input conducted by Elementary and Junior High Schools online;11. Monitor accountability reports on the use of Elementary and Junior High School BOS both offline and online; 12. Monitor the implementation of the Regular BOS program in Elementary and Junior High Schools by empowering school supervisors as regency or city monitoring teams.

Another thing in the aspect of disposition is the placement of staff, where in this case the Regent of Semarang regency assigns personnel to be responsible as the district BOS management team by making Decree number 900/2019. The last thing on the aspect of disposition is incentives and rewards. With the existence of these two things is expected to be means of control so that the staff implement policies as planned. But the team members do not get any incentives or rewards related to their assignments because they have already received salary and Additional Employee Income (TPP). From the description above, an assessment of the policy implementation for the disposition aspect if quantified is as follows:

Table 3. Evaluation for Disposition Aspect

\begin{tabular}{lc}
\hline \multicolumn{1}{c}{ Indicator } & Value \\
\hline The implementers' view to implement the program is positif and good. & $4 / 4$ \\
The implementers's commitment to implement the program is good. & $4 / 4$ \\
Implementers' expertise to support the implementation of the BOS program is good & $4 / 4$ \\
Staff placement to implement the BOS program is good & $4 / 4$ \\
There are sufficient incentives and awards to implement the BOS & $1 / 4$ \\
& Total \\
& $17 / 20$ \\
\hline
\end{tabular}

Source: Research data processed

Table 3 shows that the Disposition aspect shows a very good value that is $85 \%$. However, incentives and awards only get 1 score from total score 4 because the implementers in the BOS management team do not get incentives or rewards. However aspects of views, 
commitment, expertise and placement of staff are considered very good with a maximum score of 4.

\section{Bureaucratic Structure Factors}

Other than Permendikbud No. 3 of 2019 concerning Technical Guidelines for School Operational Assistance in 2019 which are used as work guidelines, the management team also works based on Circular Letter of the Minister of Home Affairs Number 971-7791 2018 dated 28 September 2018 concerning Technical Guidelines for Budgeting, Implementation and Administration as well as Accountability for Operational Assistance Funds Public Elementary School Education Unit organized by the regency or city on the Regional Revenue and Expenditure Budget. Based on these two Standard Operational Procedures (SOP), all members in the team have the same view on how to implement the policy. So far there is no conflict in implementing this policy, because each member understands their duties and functions.

In the implementation of the BOS program there are no Bureaucratic fragmentation, because the bureaucracy is not too long and there is a division of coordination and responsibilities, so implementation becomes more effective. Supervision is easier and procedures becomes more concise and simpler. If the quantity of the policy implementation evaluation score is quantified for aspects of the bureaucratic structure, it is as follows:

Table 4. Evaluation for the Bureaucratic Structure aspect

\begin{tabular}{lc}
\multicolumn{1}{c}{ Indicator } & Value \\
\hline There are clear SOPs or policy implementation guidelines & $4 / 4$ \\
There is no fragmentation within policy makers and implementers & $4 / 4$ \\
Total & $8 / 8$ \\
& Source: Research data processed
\end{tabular}

Table 4 shows that the aspects of the bureaucratic structure are not constrained because there are SOPs as guidelines for implementation and also there is no fragmentation between policy makers and policy implementors. So if we combine the assessment of all aspects of communication, resources, disposition and organizational structure, the quantity will look like the following table.

Table 5. Evaluation of Implementation Policy on Management of School Operational Fund (BOS) in the Department of Education, Culture, Youth and Sport - Semarang Regency

\begin{tabular}{lllcc}
\hline Aspek & \multicolumn{2}{l}{ Indicator } & Value \\
\hline Communication & 1. & $\begin{array}{l}\text { There are good communication channels, between } \\
\text { policy makers and policy implementers, the } \\
\text { implementation team and budget users }\end{array}$ & $83 \%$ \\
& &
\end{tabular}




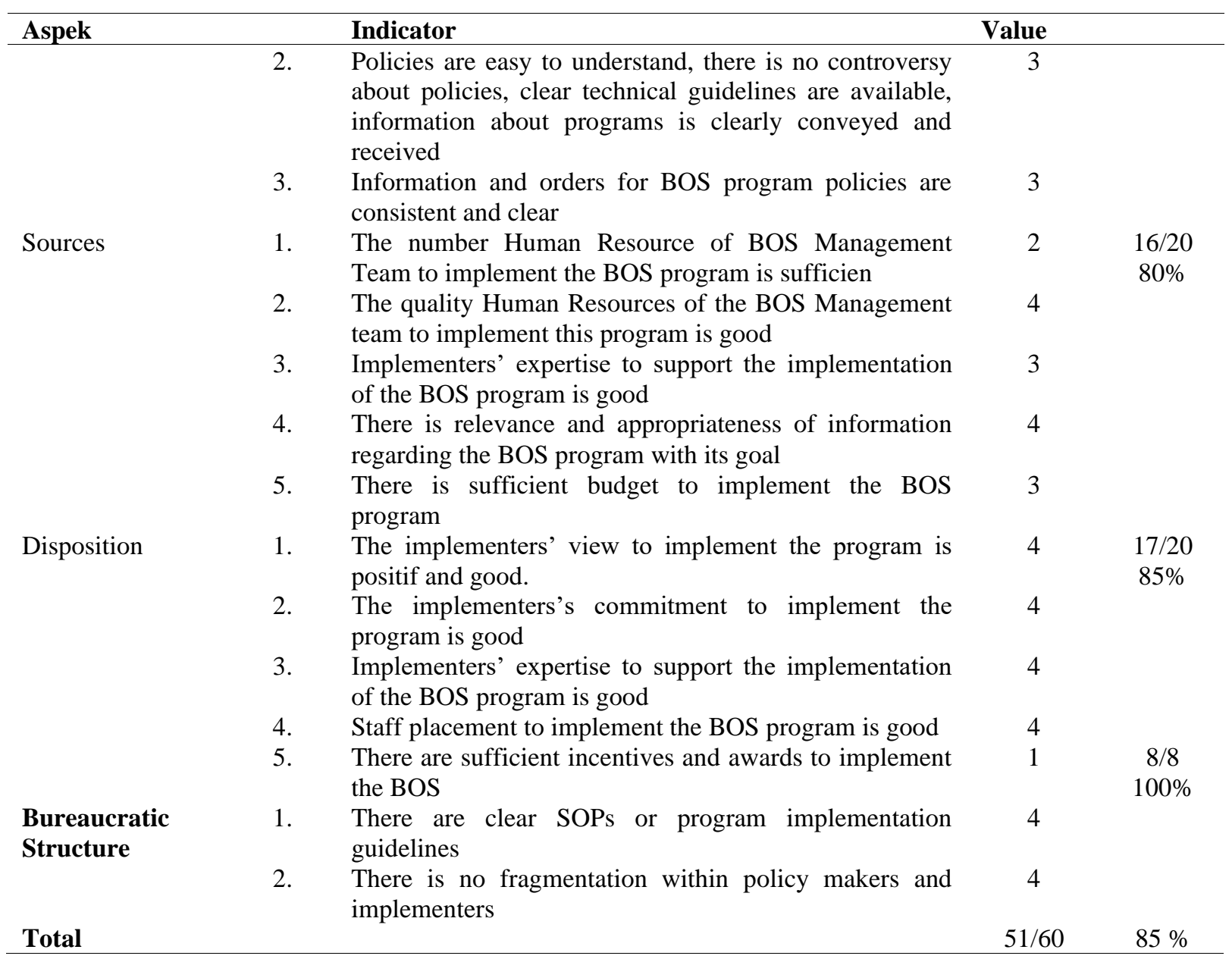

\begin{tabular}{lcc}
\hline & Categories & Scale \\
\hline Bad & $1-15$ \\
Not really good & $16-31$ \\
Good & $32-44$ \\
Very Good & $45-60$ \\
\hline
\end{tabular}

Because the score obtained is 51 out of a total of 60 , the rate of scores in the category is very good. With this result we can recommend to the Semarang Regency Education Department, especially the BOS management team to maintain their performance, or improve it so that they can get the maximum score.

\section{Discussion}

As mentioned in the introduction, the BOS program is a form of service provided by the government in the field of education. The program, which began in July 2005, is expected to accelerate the achievement of the 9-year compulsory education program. The 
implementation of the BOS program is carried out by implementing organizations starting from the central level implementers, namely the Central BOS Management Team, the Provincial Management Team, the BOS Management Team at the city or regency level up to the School Management Team.

This study evaluates the implementation of BOS management carried out by the Education Department Semarang Regency using Edward III model that focuses on 4 aspects, namely communication, resources, disposition and bureaucratic structure. These four factors are indispensable for a policy to be carried out successfully.

\section{Communication}

According to George C. Edward in Budi Winarno (2008: 174) the communication factor is one of the variables that must be considered if the policy makers want to implement policies smoothly without obstacles. Policy makers hope that decisions or orders can be transmitted to implementers in the field. Clarity of communication is very important so that the policy implementation process is in accordance with the initial objectives of a policy. There are three aspects to communication, namely transmission, clarity and consistency.

Permendikbud Number 3 of 2019 as technical guidelines for BOS management and Circular of the Minister of Domestic Affairs Number 971-7791 of 2018 are used as a reference for communication transmission. Information distortion does not occur because the level of bureaucracy is not too long and layered. Reports on the use of BOS funds are sent from the Central Java provincial BKUD (Regional General Finance Agency) directly to the school account so that the district education office is only tasked with monitoring. Because the technical instructions for implementation are clear so it eases the implementers to implement the policy. Beside that there are many socializations of the technical instructions on regular basis.

According to Edward III (1980: 26) there are six (6) factors of clarity that influence the unclear communication in policy implementation, namely the complexity of public policy, the unwillingness to disturb community groups, the lack of understanding of policy objectives, problems which arises in initiating a new policy, avoiding policy accountability and the nature of court decision-makers. The BOS policy is quite complex or complicated in terms of reporting, because in addition to having to report it to the central government, the team must also report it to the regional government with a different format. If seen from the desire not to disturb community groups, the management of BOS actually intends to help poor communities to send their children to school so that the 9-year compulsory education 
program can be implemented. The results of the study also show that the implementers know clearly the purpose of implementing this BOS policy.

The problem arises when there is a change in the Technical Guidelines in October 2019. Initially the technical guidelines used were technical number 3 of 2019, replaced by technical no. 18 of 2019 and finally number 35 of 2019. This change involves how to buy school supplies that must go through the SIPLah application where all the buying and selling processes must be done online to be more transparent. This new policy raises a slight problem, because not all goods providers are able to make SIPLah applications. There are no members of the BOS management team in the Education Office who deliberately avoid policy accountability. The team always carries out its tasks and functions including training, fostering, verifying, recapitulating reports on the realization of regular BOS fund.

The third thing in the aspect of communication is consistency. If the implementers consistently implement the implementation instructions, the communication will run better, so that implementation will also be better. Inconsistency occurs in the BOS technical implementation guidelines which have been revised three times in just one year. With this revision the implementation in the field has also changed.

The theory of implementation gap states that there are differences between the solutions adopted in legal documents and the actual implementation in practice (CIPE, 2012,1). It is stated that the implementation gap could be caused by three factors; political factors, economic factors and social and cultural factors. CIPE (2012: 14-17). This inconsistency is influenced by political factors because the central government wants a transparent and accountable or trusted system, so that all procurement of goods and services organized by schools can be documented online by using the SIPLah application. However, in reality, almost all schools cannot apply this because, the system is rather complicated and therefore not all traders use this application. This causes a drop in the procurement of goods and services at school, which automatically disrupts the teaching and learning process at school.

The finding from this research is quite different compared to similar study taken by Nurtje Irine Djoys Guyen (2014) entitled Implementation of policy for distributing BOS School Operational Assistance funds for the Youth and Sports Education in the Aru Islands Regency. In her research she found that there were problems for communication aspect in distributing the BOS fund for examples lack of socialization of the technical instructions, 
distribution process was not timely and problems in conveying the information about free school so there were pro and contra opinions among the society.

Resources

Edwards III said that if there were insufficient resources, the implementation of the policy would not be effective (1980: 53). Human Resources, Facilities, Information and Budget are the important aspects of Resources. For Human Resources, when the number and skills are sufficient, the instructed policy also tends to be implemented well. From the Decree of the Regent No. 900/2019, the number of BOS management team in the Education Office Semarang Regency consists of 16 people who have the position and main tasks and functions respectively from the director. This number is not sufficient to handle the management of BOS funds, because there are more than 600 schools need to be handled, resulting in a slight overlap in responsibilities. One person should manage each data, either elementary or secondary high school data, yet in the field these two data are managed by one person. From the implementation gap theory, this can be seen from the political factors in the aspects of the state bureaucracy, as for the procurement and appointment of staff, especially civil servants, or honorarium employees, must go through a long bureaucracy. Since decentralization the mechanism for hiring personnel has been left to the regional government. In terms of skills, all implementers are able to carry out their duties because their educational background are bachelor or master degree. In addition, because there are frequent trainings and outreach from related agencies regarding the implementation of BOS so the implementation team's skills are getting better.

Edward III's theory states that existing facilities determines the success of a policy. However, the BOS management team's work space is too narrow, so the staff are less comfortable and less flexible with their activities. This 60 square meter room is a place for 7 people to work. The room is filled with stacks of hard files in the form of reports from approximately 600 schools. However, the management team still carry out their main tasks and functions. In the implementation gap theory, regarding the limitations of facilities, is closely related to bureaucratic factors, where for the procurement of space and goods needed, it must also go through a quite long and complicated levels of bureaucracy.

According to Edward III there are two forms of information, namely information about what procedures how to implement a program and the second is about implementing compliance with existing orders or instructions. The information used as a work guide are the Technical Implementation instructions and Circular Letter as mentioned above. From the two guidelines, the executors do their duties and try to obey the existing guidelines. 
The final aspect of Resources is the Budget factor. In Edward III's theory stated that the budget will determine the success or failure of a policy. In implementing BOS policy the special budget allocated for implementing this policy is sufficient. The budget is included in the State Budget (APBN) which covers all the funding needed by the Education Department Semarang Regency. The minimum number of Human Resources and the professionalism or quality of HR doing the implementation are some similarities with the research done in Aru Island.

\section{Disposition}

Edward III (1980: 89) said that when a policy maker instructs a policy implementation and the executor receives the instructions properly, then the policy implementation will be carried out well too. But on the contrary if the implementer does not receive the instructions properly, the possibility of implementation will experience difficulties or failures. BOS management team has a tendency of a positive outlook towards BOS policies from the central government. The executor can carry out the instructions contained in the technical instructions and Circular Letter. This is shown from all the results of audit bodies such as the Supreme Audit Board (BPK) and from district and provincial inspectorates for the implementation of BOS funding in Semarang Regency always shows fair results without exceptions (WTP). This is certainly inseparable from the commitment of all program implementers of the BOS management team. The commitment and willingness of implementing the policies to implement the BOS program is very good, marked by the commitment of the Education Department Semarang Regency to support the success of the 9year compulsory education program. This finding is similar to the research done by Nurtje in Aru Island (2014) where she found out that the implementers of the program from the regional government through the school staffs, they all had positive attitude toward the BOS policy. The implementers had the same perception that BOS policy must be supported to be successful. Both studies revealed that one of supportive actions done by the local government was the existence of BOS Assistance Funds from the Regional Finance for all schools in both regencies. These proved that the implementers had commitment to support the policy.

In disposition aspect, there must be an aspect of implementing expertise, where the staff must have a good educational background or skills to carry out the program. The BOS management team always upgrades the expertise of the implementers by frequently sending to training and disseminating information on managing BOS funds at both the provincial and 
central levels. This management and BOS training is also socialized to BOS fund users at the school level at least annually, every time there is a new technical guide or circular, or every time there is a change in technical guidelines. Edward III in Budi Winarno (2012: 200) said that in appointing staffs or bureaucrats, sometimes it was not merely seen from its capacity to occupy a certain position, but rather it was more directed to political considerations, such as to accommodate various interests. The staff placement in the regular BOS management team has been formed by the Regent of Semarang Regency by issuing the Regent's Decree Number: 900/2019 concerning the Formation of the Semarang Regency Regular School Level Operational Management Team for the 2019 budget year.

Edward III in Budi Winarno (2012: 200-201) said that one of the techniques suggested to overcome the problem of the implementers' tendency is by manipulating incentives. Because people generally act in their own interests, so manipulating incentives by high-level policy makers is likely to influence the actions of policy implementers. However, the results of the study do not reveal any incentives and awards given to the BOS management team in the Education Department of Semarang Regency because they already have a TTP or Additional Income Benefits outside the salary they receive. If seen from the implementation gap theory, it is related to political factors because the government has issued Permendagri No. 21 of 2011 concerning Regional Governments to provide additional income to PNSD (Regional Civil Servant) based on objective considerations by taking into account regional capabilities.

\section{Bureaucratic Structure}

In the bureaucracy there are structures, rules and mechanisms to carry out policy activities from the government in which there must be a Standard Operational Procedure (SOP) containing a step guideline in the form of a pattern in carrying out policy implementation. Based on two things as technical guidelines namely Permendikbud no 3 2019 and Circular Minister of Home Affairs Number 971-7791 2018 as the two SOPs, it can be said that the bureaucracy in this management team is very good.

The second characteristic of the bureaucratic structure is fragmentation. Edward III said in Budi Winarno (2012: 206) that fragmentation came from pressures outside bureaucratic units, such as the legislative, executive, state constitutions and the nature of policies that affect the organization of government bureaucracies. Fragmentations do not occur in the BOS management team in Semarang Regency, because there are similar views on how to implement the program among all stakeholders. In addition, the implementation also involved all the existing stake holders from the Semarang Regent as the BOS program 
director to the program implementers at the education unit level who had the same view in implementing this program.

There are similarities between this research compared to the study done by Nurtje in Aru Island in term of Bureaucratic Structure as for SOP, the BOS team in Aru island used Permendikbud Number 51 of 2011 as technical guidelines and Semarang Regency used Permendikbud Number 3 of 2019. Both studies showed that there was no fragmentation in the implementation event though this policy involved many bureaucratic layers.

The result of the research can be described that according to Edward III Model, there are four variables that must be considered if the policy makers want to implement policies successfully without obstacles. They are Communication, Sources, Disposition and Bureaucratic Structure. Those four factors should be fulfilled so that the implementation of a policy is successful. This research shows that the implementation policy on management of School Operational Fund (BOS) 2019 in the Department of Education, Culture, Youth and Sport - Semarang Regency is in very good category as they get total value of $85 \%$.

The Edward III model is the novelty of this evaluation research. Most evaluation researches use common models to evaluate a policy or a program for instance CIPP model, Kirkpatrick model, Wheel model or Stake Model. Although there are some researches also uses Edward III model, they mostly use it to describe only certain point and not the whole aspect of a policy. For example, the research of Nurtje in Aru Island (2014) that only describes how the BOS fund is distributed to school units, while this research evaluate the whole aspects of how Education Department in Semarang Regency manages the BOS funds.

\section{Conclusion}

The research shows that the implementation of BOS policy is considered very good with the achievement of $85 \%$ assessed from four aspects. Communication aspect is very good, because there is good communication between policy makers and the policy implementation team. Information about this program is consistent and clearly conveyed and received by the implementation team. What needs attention is the consistency factor, where the technical guidelines used in 2019 has been revised three times, resulting in inconsistencies. For Resources, the number of the implementation team is still lacking while the quality of human resources is considered good because most of them have bachelor degrees and often gets special training and socialization. Facilities do not get maximum score 
because the room used by the team is too narrow. The budget gets maximum score because the budget allocated for implementing the program's policies is sufficient. The last aspect for communication is there is relevance and compatibility of information about the BOS program with the objectives stated in the implementation guidelines.

A good assessment also exists on the Disposition aspect, where the BOS management team's views on BOS policy always support all policies triggered by the government related to BOS policies. Their commitment to the success of the BOS program is also not to be doubted. The clear evidence is that financial statements are always Fair without Exception (WTP) when audited by Audit Board or BPK. Implementing expertise is also considered good, because all the main tasks and functions written in the implementation instructions have been carried out. Staff placement is also considered very good, because Semarang Regent has issued a decree regarding the formation of the School Operational Assistance Management Team. For incentives and awards does not get maximum score because no incentives or awards given to the BOS management team. The bureaucratic structure is considered very good because there are already Standard Operating Procedures (SOP) in the form of technical guidelines for Implementation and Circular from the Minister of Home Affairs to implement the BOS policies. For Fragmentation, there was no division between policy makers and implementers in implementing this BOS policy

The assessment of all aspects; communication, resources, disposition and bureaucratic structure of the BOS Policy Implementation is in very good category and recommended to be continued with various improvements by the local government of Semarang Regency. The first is the need to provide adequate space as well as cupboards to keep all hard copies of reports from schools as facilities for the management team to carry out their duties. The second is the need to increase the number of Human Resources for the BOS management team tasked with managing BOS fund. For incentives and awards also need to be considered by Semarang Regency government considering the implementation of the BOS management team does not get any incentive in implementing this BOS policy, even though there was a TPP or Additional Employee Income.

\section{References}

Afifudin \& Beni Ahmad Saebani.2009 Metodologi Penelitian Kualitatif, (Bandung: CV Pustaka Setia), hlm 134

CIPE. 2012. (Center for International Private Enterprise and Global Integrity); Improving Public Governance, Closing the Implementation Gap Between Law and Practice 
Creswell, John W. 2010. Research Design: Pendekatan Kualitatif, Kuantitatif, dan Mixed.Yogyakarta:Pustaka Pelajar.

Gunawan, Imam. 2014. Metode Penelitian Teori dan Praktik, (Jakarta: Bumi Aksara), hlm 160

Iskandar. 2009.Metodologi Penelitian Pendidikan dan Sosial (Kuantitatif \& Kualitatif), (Jakarta: GP Press) hlm.230-231.

Kaswandi. 2015. Evaluasi Pengelolaan Dana Bantuan Operasional Sekolah di SD Negeri 027 Tarakan. Jurnal Kebijakan dan Pengembangan Pendidikan. Vol.3 No.1: 66-74. Pengawas Dinas Pendidikan Tarakan.

Moloeng, Lexy J. 2009. Metodologi Penelitian Kualitatif, (Bandung: PT Remaja Rosdakarya).

Majid, Latief Abdul \& Jamil. 2015. Evaluasi Pelaksanaan Program Bantuan Operasional Sekolah (BOS) Sekolah Menengah Pertama. Jurnal Utilitas. Vol. No.1:36-102.FKIP. Universitas Muhammadiyah

Neolaka, Amos. 2014. Metode Penelitian dan Statistika, (Bandung: Remaja Rosdakarya, 2014), hlm 22

Setiawan, Guntur. 2004. Implementasi Dalam Birokrasi Pembangunan. Jakarta: Cipta Dunia

Silele, Erdiani dkk. 2017. Evaluasi Pengelolaan Dana Bantuan Operasional Sekolah (BOS) (Studi Kasus Pada SD Inpres 4 Desa Akediri Kecamatan Jailolo Kabupaten Halmahera Barat). Jurnal EMBA. Vol. 5 No.2: 1626-1635. FEB.Universitas Samratulangi

Arikunto, Suharsimi. 2013.Prosedur Penelitian Suatu Pendekatan Praktik. (Jakarta: Rineka Cipta, 2013), hlm 172

Sulistyaningrum, Eny. 2016. Impact Evaluation of the School Operational Assistance Program (BOS) using the Matching Method, Journal of Indonesian Economy and Business Volume 31, Number 1, , 33 - 62

Sugiyono, 2010.Metode Penelitian Pendidikan Pendekatan Kuantitatif, Kualitatif, dan R\&D (Bandung: Alfabeta, 2010), hlm. 338

Wahab, Abdul, Solichin. 2008. Analisis Kebijaksanaan, Dari Formulasi Ke Implementasi Kebijaksanaan Negara. Jakarta: Bumi Aksara

Widyatmoko, Subkhi \& Suyatmini. 2017. Pengelolaan Dana Bantuan Operasional Sekolah di SD Kemasan 1 Surakarta. Jurnal Manajemen Pendidikan. Vol.12 No.2: 153-160. Magister Administrasi Pendidikan Sekolah. UMS.

Winarno, Budi. 2005. Kebijakan Publik (teori, proses, dan studi kasus). Yogyakarta: CAPS (Center of Academic Publising Service). 